\title{
Evaluasi Kinerja Peternak Mitra Ayam Ras Pedaging
}

\author{
Performance Evaluation of Farmer Partner of Broiler Chicken Race \\ K.T. Arum ${ }^{1}$, E.R. Cahyadi ${ }^{2}$, A. Basith ${ }^{2}$ \\ ${ }^{1}$ Mahasiswa Pascasarjana Fakultas Ekonomi dan Manajemen IPB \\ ${ }^{2}$ Dosen Jurusan Ilmu Manajemen Fakultas Ekonomi dan Manajemen IPB \\ E-mail corresponden author : kartikatirta@gmail.com
}

\begin{abstract}
Broiler chicken had a great performance with unique characteristics like rapid growth, had a thick meat, and also had a relatively short breeding time. The breeding management became one of the farmers key success in describing their management system effectively. One of the management function was the evaluation, thus the research purpose was to evaluate the performance of partnership farmers as the partner of PT XYZ. This research was using the observation and interview methods to the company's side and also the ones who was involved in the farmers performance evaluation process. The data that was used in this research was the secondary data that was gathered from the company's yearly report, and was seen by the farmers index performance (IP). This study took 36 breeders as the sample, 216 periods in 2017 for 6 production cycles. Data were analyzed using a control chart. Data analysis indicates IP Score less than 300 goes to underperformed, 301-325 is considered enough, while a score of 326 - 350 goes to good. As for great and outstanding there are no farmers yet in those segments. The highest IP score for partnership farmers is 335 and the lowest was 277. Partnership farmers in category "enough" are 69,44\%, "good" 11,11\% and "underperformed" 10,44\%. Upper Control Limit (UCL) is 344,36 and Low Control Limit (LCL) is 278,65 wit Mean value of 311,50. There are two points less than LCL, in 19th and 210th points, scoring 277 and 278.
\end{abstract}

Keywords: performance evaluation, broiler chicken, index performance, control chart.

\section{PENDAHULUAN}

Usaha peternakan ayam ras pedaging di Indonesia semakin berkembang terlihat dari hulu sampai hilir banyak perusahaan yang bergerak di bidang peternakan khususnya ayam ras pedaging. Total produksi daging tahun 2016 sebanyak 3,4 juta ton, produksi daging terbesar disumbang oleh ayam ras pedaging yaitu 56,77 persen, sapi dan kerbau 16,40 persen, babi 10,12 persen, dan ayam buras 8,49 persen (Kementrian Pertanian 2017). Berdasarkan data dari BPS (2018), Indonesia merupakan negara dengan jumlah penduduk 265 juta jiwa, diketahui bahwa laju pertumbuhan penduduk saat ini diangka 1,49 persen yang berarti dalam satu tahun penduduk Indonesia bertambah sekitar 4 juta jiwa. Meningkatnya pertumbuhan penduduk berpengaruh terhadap peningkatan kebutuhan pangan masyarakat yang terlihat dari data produksi daging setiap tahun mengalami peningkatan.

Peningkatan jumlah penduduk setiap tahunya menjadi suatu peluang pasar untuk mengusahakan ternak ayam ras pedaging. Daya tarik dari usaha ayam ras pedaging adalah waktu pemeliharaan yang sangat singkat dibandingkan jenis ternak lain, perputaran modal yang cepat, modal yang dibutuhkan cukup besar, baik modal investasi maupun modal operasional (Rasyaf 2002). Dalam menjalankan usaha budidaya ayam ras pedaging, peternak memiliki banyak kendala seperti lemahnya kemampuan pembudidaya ternak, biaya produksi yang masih tinggi, keterbatasan modal dan sulitnya mendapat pasokan sarana produksi yang berkualitas tinggi secara kontinyu seperti bibit (DOC), dan sulitnya aspek pemasaran (Daryanto 2007). Keberhasilan usaha peternakan ayam ras pedaging dipengaruhi oleh banyak faktor salah satunya bibit (DOC), pakan, serta manajemen pemeliharaan. Keadaan ini yang mendorong terbentuknya peternak untuk melakukan kemitraan dengan perusahaan perunggasan dan poultry shop.

Pola kemitraan yang banyak dilakukan oleh peternak ayam ras pedaging adalah pola kemitraan inti plasma dengan sistem kontrak. Kemitraan merupakan kerjasama yang saling menguntungkan antara inti dan plasma dimana inti menyediakan sarana produksi seperti bibit (DOC), pakan, obat dan vaksin serta petugas lapang. Sedangkan plasma menyediakan kandang, tenaga kerja dan operasional. Manfaat kemitraan bagi peternak adalah kemudahan mendapatkan sarana produksi, terjamin harga dan pasar, serta mendapatkan penyuluhan pemeliharaan selama proses produksi. 
Salah satu perusahaan peternakan yang melakukan kemitraan dengan peternak ayam ras pedaging di Kabupaten Banyuwangi adalah PT XYZ yang telah melakukan usaha selama 11 Tahun. Perusahaan mempunyai standar produksi untuk menghasilkan ayam yang bermutu tinggi, dengan Indeks Performance (IP) diatas nilai 300. Nilai IP menunjukkan suatu keberhasilan proses produksi ayam ras pedaging dalam satu periode yang dipengaruhi oleh Kematian, FCR, Bobot badan dan Umur panen. Salah satu yang menjadi acuan untuk pemberian bonus bagi peternak mitra dengan ketentuan yang ada pada kontrak seperti nilai IP. Apabila nilai IP rendah maka ayam yang dihasilkan pada periode tersebut bermasalah sehingga perusahaan inti memutuskan untuk di chick-in kembali atau tidak dengan pertimbangan salah satunya nilai IP. Peternak mitra PT. XYZ dalam menghasilkan nilai IP diatas 300 sangatlah susah karena semua peternak mitra menggunakan kandang tradisional panggung yang terbuat dari bambu dan kayu. Manajemen pemeliharaan sangat penting dalam mencapai nilai IP diatas 300 serta pengetahuan peternak terhadap penyakit, diharapkan oleh perusahaan agar peternak selalu lapor kepada petugas lapang agar ayam yang dipelihara sesuai dengan standar produksi perusahaan.

PT. XYZ setiap tahun selalu mengevaluasi nilai IP peternak mitra yang hasilnya dari tahun ke tahun selalu mengalami penurunan. Lima tahun pertama rata-rata nilai IP peternak mitra di atas 315 , sedangkan tiga tahun terakhir nilai IP rata-rata peternak mitra 290. Penurunan rata-rata nilai IP dikarenakan peralatan dan umur kandang yang sudah tua sehingga perlu adanya perbaikan pada lantai kandang, tirai, jumlah pemanas, jumlah tempat makan dan minum yang tidak sesuai dengan standar produksi serta semakin lama peternak dalam budidaya ayam semakin tidak disiplin dalam persiapan ayam saat chick-in dan istirahat kandang. Perusahaan dalam mengevaluasi peternak mitra yang telah bergabung menggunakan salah satunya dengan nilai IP agar mendapatkan mitra dalam kerjasama yang berkualitas tinggi serta menghasilkan ayam yang sesuai standar perusahaan. Evaluasi sangat membantu peternak dan perusahaan dalam menemukan masalah yang ada dan selanjutnya memperbaiki hal tersebut agar dapat berjalan lebih optimal dibandingkan sebelumnya. Penetapan nilai rata-rata IP peternak oleh kepala produksi dan manajer area serta disesuaikan dengan peraturan pemberian bonus oleh perusahaan. Evaluasi terhadap kinerja peternak dilakukan setiap periode dalam satu tahun untuk memberikan batasan nilai IP agar sistem dalam perusahaan dapat berjalan sesuai dengan tujuan yang telah ditetapkan. Tujuan penelitian mengevaluasi kinerja peternak mitra menggunakan nilai IP pada PT XYZ selama tahun 2017.

\section{MATERI DAN METODE}

Penelitian dilakukan di PT XYZ yang berada di Kabupaten Banyuwangi, Provinsi Jawa Timur. Pemilihan lokasi penelitian dilakukan secara sengaja (purposive method) karena Kabupaten Banyuwangi merupakan salah satu sentra produksi ayam ras pedaging di Jawa Timur dan potensi lahan di Kabupaten Banyuwangi masih cukup besar untuk dikembangkan sektor peternakan. PT. XYZ meupakan pionir kemitraan ayam ras pedaging di Kabupaten Banyuwangi dengan total populasi pada tahun 2017 sebanyak 660.000 ekor. Wilayah peternakan PT. XYZ tersebar di 18 Kecamatan dari 24 total kecamatan yang ada di Kabupaten Banyuwangi. Kegiatan penelitian dan pengumpulan data dimulai pada tanggal 8 - 15 April 2018.

Jenis data yang digunakan terdiri atas data primer dan data sekunder. Pengumpulan data melalui (1) pengambilan data dan informasi peternak mitra PT. XYZ yang menjadi contoh; (2) observasi dengan membuat daftar pertanyaan (kuesioner) dan wawancara mendalam dengan perwakilan manajemen, yang diarahkan oleh pewawancara untuk tujuan memperoleh informasi yang relevan berisi pertanyaan-pertanyaan yang difokuskan untuk menjawab masalah penelitian; (3) studi kepustakaan. Populasi contoh yang digunakan dalam analisis data menggunakan grafik kendali adalah seluruh peternak mitra PT. XYZ dengan lama beternak lebih dari satu tahun terakhir pada tahun 2017 yang terdiri dari enam kali periode. Responden peternak mitra yang dipilih sebanyak 36 orang yang terdiri atas 216 periode dari populasi 38 orang yang terdiri atas 222 periode. Nilai IP diperoleh dari rekapan hasil produksi peternak selama tahun 2017. Variabel penelitian yang diamati adalah nilai IP per periode, penyebab terjadinya nilai IP rendah, dan penyebab terjadinnya nilai IP tinggi.

Heizer, Render (2014) menyatakan bahwa Grafik pengendalian (control charts) adalah presentasi grafis dari proses data dari waktu ke waktu yang menunjukkan batas kendali atas dan bawah untuk proses yang ingin dikendalikan. Grafik yang digunakan untuk menentukan apakah suatu proses berada dalam keadaan in control atau out control. Batas pengendalian yang meliputi batas atas (upper control limit) dan batas bawah (lower control limit) dapat membantu untuk menggambarkan kinerja yang diharapkan dari suatu proses, yang menunjukkan bahwa proses tersebut konsisten (Ariani 2002).

Tahapan yang dilakukan dalam pengolahan data, yaitu (1) Pemeriksaan dan penyesuaian terhadap data yang telah diperoleh; (2) Memindahkan data yang telah diperoleh ke dalam Miscrosoft Excel yang digunakan untuk analisis data; (3) Memasukkan data nilai indeks performance (IP) peternak per periode selama satu tahun; (4) Menghitung nilai garis pusat untukmendapatkan nilai upper control limit (UCL) dan lower control limit (LCL) dengan batasan 3 sigma dengan menggunakan Microsoft Excel yang kemudian hasil hitungnya digunakan untuk analisis grafik kendali; (5) Menghitung nilai UCL, LCL, dan CL dengan pendekatan rataan menggunakan Micrososft Excel yang mana nilai-nilai tersebut digunakan sebagai batas kendali pada grafik kendali.

Perhitungan dalam mengolah data untuk grafik kendali dengan bantuan program Microsoft Excel menggunakan rumus-rumus berikut:

\section{Central Limit (CL)}

$\mathrm{CL}=\sum$ nilai IP $/ \sum$ jumlah periode 


\section{Batas Kendali Atas (Upper Control Limit)}

$$
\mathrm{UCL}=\text { rata-rata nilai } \mathrm{IP}+3(\text { Standar deviasi })
$$

\section{Batas Kendali Bawah (Lower Control Limit)}

$$
\mathrm{LCL}=\text { rata-rata nilai IP - 3(Standar deviasi) }
$$

\section{HASIL DAN PEMBAHASAN}

\section{Karakteristik Peternak Mitra}

Karakteristik peternak mitra pada PT. XYZ meliputi jumlah ternak, usia, jenis kelamin, status usaha, jenis kandang, tingkat pendidikan dan pengalaman beternak. Jumlah ternak yang bergabung dengan PT. XYZ sangat bervariasi mulai dari yang paling sedikit 2000 ekor hingga 12500 ekor. Ketentuan dari perusahaan bahwa minimal jumlah ternak yang bergabung 2000 ekor karena untuk efisiensi pengiriman pakan, bibit/DOC, Obat dan vaksin lebih efektif dan efisien mengenai biaya transportasi. Usia peternak yang bergabung dengan PT. XYZ pada usia produktif yaitu dengan rentan usia antara 25 sampai 60 tahun. Pada usia demikian secara fisik peternak mempunyai kemampuan untuk menangani usahanya dengan baik. Sebagian besar peternak ayam ras pedaging berjenis kelamin laki-laki, yaitu sebesar 29 orang. Hal ini menunjukkan bahwa laki-laki masih dominan di dalam usaha ternak ayam ras pedaging, namum demikian masih terdapat peran wanita dalam usaha ternak ayam ras pedaging yang berjumlah 9 orang.

Tingkat pendidikan peternak ayam ras pedaging yang bergabung dengan PT. XYZ bervariasi dari SD hingga Pascasarjana. Mayoritas tingkat pendidikan formal terakhir peternak adalah SMA. Sebagian besar peternak memiliki pengalaman beternak antara satu sampai enam tahun, yang artinya masih belum banyak pengalaman dalam usaha sehingga butuh pembinaan teknis oleh petugas lapang. Peternak yang bergabung dengan PT. XYZ mayoritas sebagai pekerjaan utama. Status usaha berpengaruh terhadap keberlanjutan dari usaha ternak, ketika terjadi resiko usaha seperti ayam sakit maka peternak dengan usaha sampingan cenderung memilih untuk tidak berproduksi. Jenis kandang yang umum milik peternak adalah kandang tradisional panggung dengan bangunan kayu dan bambu serta atap dari genteng atau asbes. Jenis kandang panggung memiliki tingkat keberhasilan lebih tinggi dibandingkan dengan jenis kandang di bawah.

\section{Indeks Performa Ayam Ras Pedaging}

Salah satu kriteria yang digunakan untuk mengetahui keberhasilan pemeliharaan adalah dengan menghitung indeks performa. Indeks performa (IP) adalah suatu formula yang umum digunakan untuk mengetahui performa ayam ras pedaging. Faktor IP digunakan sebagai acuan karena selain mempertimbangkan bobot badan, konversi pakan, deplesi dan lama pemeliharaan sudah cukup lengkap untuk menilai (Sjofjan 2008). Semakin besar nilai IP yang diperoleh, semakin baik prestasi pemeliharaan ayam dan semakin efisien penggunaan pakan (Fadilah et al. 2007). Nilai indeks performa dihitung berdasarkan bobot badan siap potong, konversi pakan, umur panen, dan jumlah presentase ayam
Tabel 1. Produksi ayam ras pedaging tahun 2013 sampai dengan 2016

\begin{tabular}{lll}
\hline Tahun & Produksi (000 Ton) & Pertumbuhan (\%) \\
\hline 2013 & $1.497,9$ & - \\
2014 & $1.544,4$ & 3.104 \\
2015 & $1.628,3$ & 5.432 \\
2016 & $1.905,5$ & 17.024 \\
\hline
\end{tabular}

\begin{tabular}{ll}
\hline Rata-rata pertumbuhan (\%/tahun) & 8,52 \\
\hline Sumber : Direktorat Jendral Peternakan dan Kesehatan Hewan
\end{tabular}
2017, diolah.

Tabel 2. Kriteria nilai indeks performa ayam ras pedaging

\begin{tabular}{ll}
\hline Indeks performa (IP) & Nilai \\
\hline$<300$ & Kurang \\
$301-325$ & Cukup \\
$326-350$ & Baik \\
$351-400$ & Sangat Baik \\
$>400$ & Istimewa \\
\hline
\end{tabular}

Sumber: Bell and Weaver (2002)

yang hidup selama pemeliharaan (Medion 2010).

Bobot badan selama satu periode pemeliharaan ayam ras pedaging dipengaruhi oleh kualitas pakan yang dikonsumsi, karena ayam ras pedaging membutuhkan nutrisi yang cukup untuk menunjang proses pertumbuhan pada jaringan tubuh. Pakan yang dikonsumsi oleh ayam ras pedaging sangat menentukan pertambahan bobot badan sehingga berpengaruh terhadap efisiensi suatu usaha peternakan (Widodo 2009). Bobot badan disesuaikan dengan melihat kondisi ayam saat akan dipanen, apabila kondisi standar berat badan ayam ras pedaging $2 \mathrm{~kg}$ saat akan dipanen dengan menyesuaikan pasar Banyuwangi dan Bali. North dan Bell (1990), menyatakan bahwa faktor utama yang mempengaruhi konsumsi pakan adalah kandungan energidalam pakan dan keadaan suhu lingkungan. Bertambahnya umur dan bobot badan selama periode pertumbuhan, konsumsi akan terus meningkat sehubungan dengan meningkatnya kebutuhan zat makanan untuk hidup dan pertumbuhan. FCR adalah jumlah berat pakan yang diberikan untuk menghasilkan sutu kg berat hidup ayam ras pedaging. semakin kecil nilai FCR semakin baik hasilnya, mengindikasikan bahwa penyerapan yang lebih baik dan konversi pakan menjadi daging yang lebih optimal. Lesson dan Summer (2000), pemeliharaan ayam pedaging masih dikatakan efisien bila nilai konversi pakan masih di bawah angka dua. Umur panen rata-rata ayam ras pedaging dipengaruhi oleh permintaan pasar dan pelanggan, pemanenan dilakukan beberapa kali dimana tiap-tiap pelanggan membutuhkan umur ayam yang berbeda. Deplesi populasi artinya penyusutan jumlah ayam baik karena kematian maupun karena afkir (culling). Kematian terjadi karena sakit atau kondisi lingkunagan yang tidak bersahabat. Sementara pengafkiran diputuskan karena pertimbangan resiko dan ekonomi, serta gangguan pertumbuhan. Nilai yang diperoleh dari hasil pemeliharaan selama satu periode 
dibandingkan terhadap kriteria nilai indeks performa ayam ras pedaging.

Periode pemeliharaan yang menjadi sampel dalam penelitian evaluasi kinerja menggunakan nilai IP berjumlah 216 periode, pada periode pemeliharaan yang terjadi selama tahun 2017 dengan nilai IP kurang dari 300 masuk kriteria kurang, 301-325 masuk kriteria cukup dan 326-350 masuk kriteria baik sedangkan untuk kriteria sangat baik dan istimewa masih belum ada dari peternak mitra PT. XYZ. Untuk nilai IP tertinggi pada peternak mitra PT. XYZ dengan nilai 335 dan nilai IP terendah adalah 277. Peternak mitra dengan nilai IP baik berjumlah11,11 persen, nilai IP cukup sebanyak 69,44 persen dan nilai IP kurang sejumlah 19,44 persen.

Kunci kesuksesan dalam usaha peternakan ayam ras pedaging dipengaruhi oleh tiga faktor utama yaitu penyediaan bibit unggul, pemenuhan kebutuhan pakan dan manajemen pemeliharaan yang baik. Ketiga faktor produksi tersebut merupakan satu kesatuan sistem, apabila salah satu faktor terabaikan maka penanganan terhadap faktor yang lain tidak dapat memberikan hasil yang maksimal (Anggitasari et al 2016). Peternak dengan nilai IP yang berada dalam kategori baik harus konsisten dalam memelihara ayam ras pedaging agar nilai IP setabil pada kisaran 326-350 bahkan bisa lebih dari 351-400 dalam kategori sangat baik. Komponenkomponen dalam menciptakan nilai IP yang tinggi harus dipenuhi seperti, sanitasi, penerangan, kualitas air minum, pengaturan ventilasi untuk menyediakan sebanyak mungkin oksigen segar ke dalam kandang. Permainan buka tutup tirai sudah dilakukan sejak DOC umur enam hari. Dalam pemberian pakan, air minum, obat dan vitamin sesuai dengan dosis umur ayam, serta selalu menjaga kebersihan kandang ayam dari hewan lain seperti burung dan itik membawa virus penyakit.

\section{Analisis Grafik Kendali}

Dalam penelitian ini, grafik kendali digunakan untuk menentukan apakah nilai IP pemeliharaan yang dilakukan peternak perperiode dalam keadaan terkontrol atau tidak terkontrol. Grafik kendali yang digunakan adalah grafik kendali dengan menggunakan pendekatan rataan, yang menghasilkan himpunan batas pengendali pendekatan dengan anggapan bahwa ukuran nilai IP yang akan datang tidak akan berbeda besar dari yang diamati sebelumnya. Suatu proses dapat dikatakan tidak terkendali apabila terpenuhi, satu atau lebih dari beberapa kriteria
(Montgomery 1990), yang dapat dilihat pada Tabel 3.

Berdasarkan grafik kendali pada Gambar 1 dibawah ini, diketahui bahwa garis Batas pengendalian yang meliputi batas atas (upper control limit) dan batas bawah (lower control limit) sama pada setiap sampel. Perhitungan nilai dengan standar deviasi $(10,95233)$ sebagai perhitungan dalam mengolah data untuk grafik kendali dengan bantuan program Microsoft Excel menggunakan rumus berikut ini:

\section{Central Limit (CL)}

$$
\begin{gathered}
\mathbf{C L}=\sum \text { nilai IP } / \sum \text { jumlah periode } \\
67285 / 216=\mathbf{3 1 1 , 5 0 4 6}
\end{gathered}
$$

Batas Kendali Atas (upper control limit)

$\mathbf{U C L}=$ rata-rata nilai IP $+3($ Standar deviasi $)$

$311,5046+3(10,95233)=\mathbf{3 4 4 , 3 6 1 6}$

Batas Kendali Bawah (lower control limit)

$\mathbf{L C L}=$ rata-rata nilai IP - 3(Standar deviasi)

$311,5046-3(10,95233)=\mathbf{2 7 8 , 6 4 7 6}$

Apabila sebuah titik proporsi berada di bawah garis UCL dan di atas LCL, maka proporsi tersebut berada dalam keadaan terkendali.

Berdasarkan interpretasi grafik kendali menurut Montgomery (1990), nilai IP peternak perperiode dalam satu tahun masih berada dalam keadaan terkontrol. Hal tersebut dapat dilihat dari keadaan titik-titik proporsi yang terdiri atas 216 menyebar berbeda dalam daerah diantara garis UCL dan LCL di sekitar garis rataan yang dapat dilihat pada gambar diatas. Terdapat dua titik atau sampel yang melompat ke bawah di luar batas daerah garis LCL yaitu titik 19 dengan nilai 277 dan titik 210 dengan nilai 278 . Penyebab terjadinya nilai IP dibawah garis LCL pada titik 19 dikarenakan pekerja pada kandang yang masih baru tidak paham dengan manajemen pemeliharaan ayam di umur satu minggu sampai dua minggu yang menyebabkan kematian tinggi dan ayam kerdil karena suhu dan sirkulasi udara kandang tidak sesuai dengan manajemen pemeliharaan yang benar. Pemanas untuk bibit/DOC masih kurang jumlahnya, pada jumlah ayam 3000 ekor pemanas yang dibutuhkan empat sampai lima buah. Sedangkan di kandang pemanas yang ada hanya tiga buah yang digunakan malam hari

Tabel 3. Kriteria proses tidak terkendali

\begin{tabular}{cl}
\hline No & Kriteria \\
\hline 2 & $\begin{array}{l}\text { Salah satu atau beberapa titik diluar batas kendali } \\
\text { atau turun giliran diatas, atau di bawah garis tengah, atau giliran di atas, atau di bawah median }\end{array}$ \\
3 & Dua atau tiga titik yang berurutan di luar batas peringatan 2-sigma, tetapi masih di dalam batas kendali \\
4 & Empat, atau lima titik yang berurutan di luar batas 1-sigma \\
5 & Pola tak biasah, atau tak acak dalam data \\
6 & Satu, atau beberapa titik dekat satu batas peringatan, atau kendali
\end{tabular}

Sumber : Montgomery (1990) 


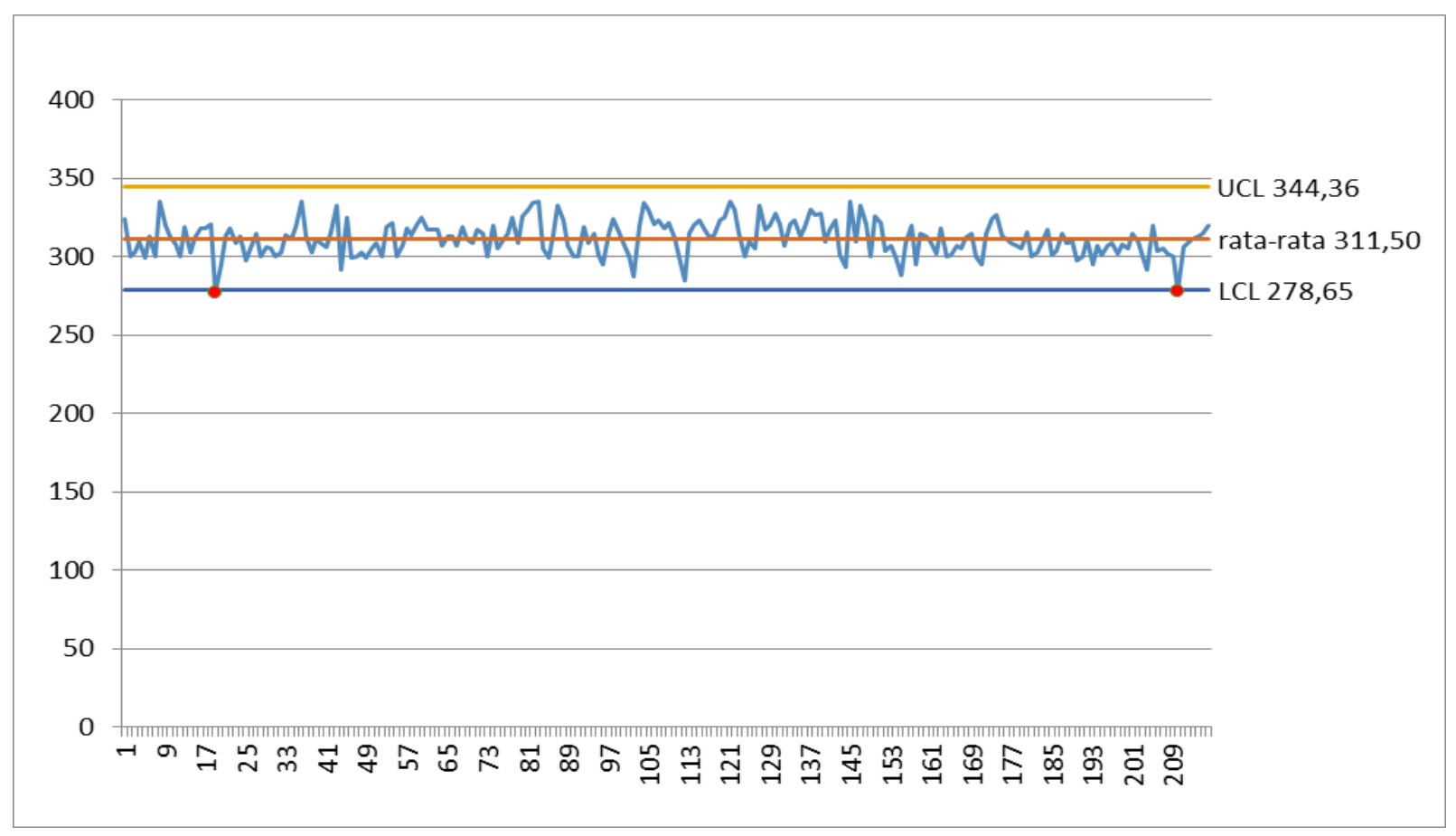

Gambar 1. Grafik kendali nilai IP

saja. Tidak sesuai dengan manajemen pemeliharaan yang menyebabkan nilai IP rendah.

Pada titik 210 yang menyebabkan nilai IP dibawah garis LCL karena wabah penyakit disekitar kandang. Lokasi kandang yang berdekatan dengan lokasi kandang ayam petelur membuat wabah penyakit pada ayam ras pedaging mudah terserang. Usia ayam diatas 20 hari dengan rata-rata bobot badan satu kg dalam satu hari mati 150 ekor selama tiga hari. Kematian yang tinggi menyebabkan ayam tidak mampu diobati dan segera di jual. Untuk itu, evaluasi kinerja peternak menggunakan nilai IP sangat baik karena dapat memeriksa penyebab terjadinya masalah dan segera mengambil tindakan perbaikan. Menurut Sonalia dan Hubeis (2013), untuk menekan penyimpangan-penyimpangan yang terjadi, perusahaan harus meningkatkan pengawasan dalam kegitan produksi. Sehingga penyebab-penyebabnya dapat lebih mudah diketahui untuk lebih lanjut dapat diambil tindakan pencegahan, maupun tindakan penanggulangan secepatnya.

\section{KESIMPULAN}

Indeks performa digunakan dalam evaluasi kinerja peternak mitra yang dilakukan oleh PT. XYZ antar periode dalam satu tahun, Indeks performa didalamnya terdapat empat parameter seperti, bobot badan (BB) rata-rata, rasio konsumsi pakan terhadap peningkatan berat badan (FCR), rata-rata umur ayam saat panen dan tingkat deplesi populasi. Pemeliharaan ayam pedaging selama tahun 2017 dengan nilai IP kurang dari 300 masuk kriteria kurang, 301325 masuk kriteria cukup dan 326-350 masuk kriteria baik sedangkan untuk kriteria sangat baik dan istimewa masih belum ada dari peternak mitra PT. XYZ. Untuk nilai IP tertinggi pada peternak mitra PT. XYZ dengan nilai 335 dan nilai IP terendah adalah 277. Peternak mitra dengan nilai IP baik berjumlah 11,11 persen, nilai IP cukup sebanyak 69,44 persen dan nilai IP kurang sejumlah 19,44 persen. Batas kendali atas bernilai 344,36 dan batas kendali bawah bernilai 278,65 serta rataan bernilai 311,50. Terdapat dua titik yang bernilai kurang dari batas kendali bawah yaitu titik 19 dan 210 dengan nilai 277 dan 278 . Tidak ada nilai IP yang melebihi batas kendali atas.

\section{SARAN}

Dalam budidaya ayam ras pedaging diharapkan peternak mitra PT XYZ yang nilai IP dibawah 300 dapat melakukan perbaikan manajemen pemeliharaan dengan cara penambahan teknologi seperti kipas angin, air minum otomatis, penambahan lampu untuk pencahayaan, setiap kandang diberi alat pengukur suhu dan kelembapan.

\section{DAFTAR PUSTAKA}

Anggitasari S, Sjofjan O, Djunaidi IH. 2016. Pengaruh beberapa jenis pakan komersial terhadap kinerja produksi kuantitatif dan kualitatif ayam pedaging. jurnal bulletin peternakan (ID) : 40(3): 187-196.

Ariani DW. 2002. Manajemen Kualitas, Pendekatan Sisi Kualitatif. Jakarta (ID): Depdiknas.

Bell, Weaver. 2002. Commercial Chicken Meat and Egg Production. $5^{\text {th }}$ Edition. Springer Science and Business Media, Inc., New York, USA.

[BPS] Badan Pusat Statistik. 2018. Jumlah penduduk Indonesia. Badan Pusat Statistika.

Daryanto A. 2007. Peningkatan dayasaing industry peternakan. Jakarta (ID) : Permata wacana lestari.

Direktorat Jendral Peternakan dan Kesehatan Hewan. 2018. Populasi unggas dan konsumsi 2013-2016. 
Jakarta (ID): Direktorat Jendral Peternakan dan Kesehatan Hewan. http://www.bps.go.id/. Diakses : 10 Maret 2018

Fadilah, Polana, Alam, Parwonto. 2007. Sukses Beternak Ayam Broiler. Jakarta (ID) : PT Agromedia Pustaka.

Heizer, Render. 2014. Operation Management: sustainability and Supply Chain Management, edisi 11. Jakarta (ID) : Salemba Empat.

Kementan. 20017. Produksi Daging Nasional. Kementerian Pertanian Repbublik Indonesia. Jakarta (ID).

Lesson S and J.D. Summer. 2000. Production and carcass characteristic of the broiler. Poult. sci. 59:786-798.

Medion. 2010. Berhasil atau Tidak Pemeliharaan Broiler. Bandung (ID) : Majalah Info Medion

Montgomery DC. 1990. Pengantar Pengendalian Kualitas Statistik [Terjemahan]. Yogyakarta (ID): Gajah Mada Unv.Pres

North M.O and D.D.Bell. 1990. Commercial Chicken Production Manual. $4^{\text {th }}$ edn. Van Northland Reinhold, New York.

Rasyaf M. 2002. Beternak Ayam Pedaging. Jakarta (ID): Penebar Swadaya.

Sjofjan O. 2008. Efek pengguna tepung daun kelor dalam pakan terhadap penampilan produksi ayam pedaging. Prosiding Seminar Nasional Teknologi Peternakan dan Veteriner. Fakultas Peternakan. Universitas Bawijaya (ID) : Malang.

Sonalia D, Hubeis M. 2013. Pengendalian Mutu Pada Proses Produksi di Tiga Usaha Kecil Menengah Tahu Kabupaten Bogor. Jurnal Manajemen dan Organisasi (ID) : 4(2):112-127.

Widodo W. 2009. Nutrisi dan Pakan Unggas Kontesktual. Universitas Muhammadiyah Malang (ID):Malang. 